\title{
PARASITIC ZOONOSES: SELECTIVE REVIEW OF SOME DISEASES IN SOUTH AMERICA
}

\author{
L. GRISI
}

\begin{abstract}
SUMMARY
Selected parasitic zoonoses which occurs in South America are of echinococcosis, taeniosis/cysticercosis and lagochilascariosis. discussed with emphasis on epidemiology, diagnosis and control
\end{abstract}

RÉsumÉ : Zoonoses parasitaires : révision sélective des plus importantes maladies de l'Amérique du Sud.

L'exposé insiste sur l'épidémiologie, le diagnostic et la prophylaxie des principales zoonoses parasitaires sévissant en Amérique du Sud. L'échinoccocose-hydatidose, le complexe teniasiscysticercose et la lagochilascariose sont plus spécialement considérés.

\section{INTRODUCTION}

Parasitic zoonoses are defined as infections caused by protozoa, helminths and arthropods which are naturally transmitted between vertebrate animals and man. Certain parasitic zoonoses represent a serious threat to humans and are responsible for substantial losses in animal production, like echinococcosis and taeniosis/cysticercosis. Other parasitic zoonoses, such as South American trypanosomosis, leishmaniosis, schistosomosis and filariosis which affect millions of people living in tropical areas are usually neglected as of economic importance in veterinary medicine. Increased importance of certain parasitic zoonoses are related to the acquired immunodeficiency syndrome (AIDS) of man. In the 13th WAAVP Conference in East Berlin, Eckert (1989) proposed the subdivision of parasitic zoonoses into «AIDSrelated parasitic zoonoses" and "other parasitic zoonoses ». More than sixty parasitic zoonoses have been reported in the literature (WHO, 1979, Steele, 1982). This article selectively reviews the most recent developments of some parasitic zoonoses which occurs in South America, with main emphasis in echinococcosis.

\section{ECHINOCOCCOSIS}

Three species of Echinococcus rudophi, 1801 are recognized in Latin America: E. granulosus (Batch, 1786); E. oligarthrus (Diesing, 1863) and E. vogeli Rauch and Bernstein, 1972. E. multilocularis Leuckart, 1863 geografic distribution is limited to the Northern Hemisphere (Rausch, 1967).

Universidade Federal Rural do Rio de Janeiro, km 47 Rodovia Rio-S.-Paulo, 23851 Itaguai, RJ, Brazil.
E. granulosus have as definitive hosts carnivores and is adapteded to domestic dogs and a large number of domestic and sylvatic animals as intermediate hosts. The metacestode forms in the intermediate hosts is refered as hydatid cysts. It is a major public health problem and cause significant economic losses. In regions of North America and Eurasia the definitive host are wolves and intermediate hosts are wild ungulates, mainly moose and wild reindeer, and are not infective to domestic ungulates (Cameron, 1960). It is suggested that this is the original life cycle of $E$. granulosus in nature (Rausch, 1967).

The life cycle of $E$. granulosus in domestic animals are commonly refered as the pastoral form and includes the transmittion among dog/sheep, dog/cattle, dog/swine, and dog/horse. In Ireland, Great Britain and Western Europe, strains of E. granulosus recovered from the dog/horse cycle has been found to be morphologically and biologically different from those collected from the dog/sheep cycle (Hatch and Smyth, 1975; Thompson and Smyth, 1975; Williams and Sweatman, 1963). Also in U. S. S. R. differences have been demonstrated between cestodes recovered from the $\mathrm{dog} /$ sheep cycle and the dog/swine cycle and they were noninfective between both intermediate hosts (Kuznetsov et al., 1977; Zenkov, 1971). In a recent study of hydatic disease in urban areas of Western Australia, cysts found in grey kangoroos were well developed and most contained protoscoleces, and the cysts found in fetal pigs were degenered, small, rarely contained fluid and produced an intensive host response. It is suggested that the parasite was introduced recently to Western Australia by domestic dogs used for pig hunting (Thompson et al., 1988).

The life cycle in South America includes the tipical pas- 
toral form with domestic dogs/sheep/cattle/swine. Foxes of the genus Dusicyon are highly susceptible to experimental infections and have been found naturally infected in Argentina (Blood and Lelijveld, 1969; Schantz et al., 1972, 1975, 1976). The prevalence of echinococcosis is higher in Uruguay, Argentina, Chile, Bolivia, Central Peru, and southern Brazil. During the years of 1962 and 1971 the human infection rate for rural residents in Uruguay, was 123.0 per 100,000 (Purriel et al., 1974). Recent reports on the prevalence of echinococcosis in South America showed a significant decrease in the percentage of infection in dogs and sheep in areas where control programs are in progress. In the province of Rio Negro -Argentina after ten years (1978-1988), the infection rate of dogs dropped from $41 \%$ to $3 \%$, and hydatic cysts in sheep and man from $61 \%$ to $12 \%$ and $1.45 \%$ to $0.35 \%$, respectively (Larrieu et al., 1989). In Chile a control program was initiated in 1982, in the provinces of Aysen, Coyhaique, General Carrera and Capitán Prat. The percentage of infection after six years showed a decrease of $80 \%$ to $36.1 \%$ in sheep, $54 \%$ to $6.5 \%$ in dogs, and 79.9 to 45.1 cases per 100,000 in the population (Ogueta, 1989; Ogueta et al., 1989). In the State of Rio Grande do Sul-southern Brazil, the prevalence of hydatidosis in cattle and sheep from 1978 to 1983 , was $30.8 \%$ and $26.2 \%$. The estimated economic impact based only on liver losses is about 5 millions de dollars. A recent projection for the year 2003 during Federal Inspection data showed that the infection rate in sheep will decrease to $11.04 \%$, but the expected rate for cattle will increase to $50.7 \%$ (Costa et al., 1989). A serious economic and human health problem can be expected in Brazil in the coming years related to the dispersion of $E$. granulosus into the extensive cattle beef areas in the Central and Central west regions where more than 50 million head of cattle are grazed. An increase in the infection rate of dogs and cattle within the " pantanal region ", the temporary swamps areas of Brazil, one of the most populated areas of wildlife animals in the earth, can also bring some new epidemiological implications in the transmission of E. granulosus.

E. oligarthrus was described by Diesing in 1863 and wild felids are definitive hosts in Latin America: the cougar, Felis concolor; the jaguar, $F$. onca; the pampas cat, $F$. colocolo; the jaguarundi, $F$. yagouaroundi; the Geoffroy's cat, $F$. geoffroyi. This specie develops in domestic cats but do not reach maturity in dogs (Sousa and Thatcher, 1969). The agouti (Dasyprocta punctata) has been confirmed as intermediate host by experimental transmission to domestic cat in Panama (Sousa, 1970). On the basis of cyst morphology and size of hook from protoscolex, others intermediate hosts were identified in Latin America. D. ogouti in Brazil and spiny rat (Proechimys panamensis) in Panama (Sousa, 1970), P. pialis in Colombia (Thatcher, 1972), D. rubrata in Venezuela (Sousa and Thatcher, 1969), and Microcavia australis in Argentina (Schantz and Colli, 1973). No human infection caused by $E$. oli- garthrus has been confirmed by artificial infection of domestic cat.

E. vogeli-Description of E. vogeli by Rausch and Bernstein in 1972 it is recent if we compare with the other species of Echinococcus: E. granulosus; E. multilocularis and E. oligarthrus. The definitive host a bush dog, Speothos venaticus was described in Ecuador and the major intermediate host the paca Cuniculus paca, although agoutis and spiney rats have been found infected (D'Alessandro et al., 1979; Rausch et al.; 1978). For this specie, domestic dogs are adequate host but cats are not susceptible. Live cysts recovered from two Colombian patients were fed to dogs and E. vogeli was recovered (D'Alessandro et al., 1979). The previous reports of polycystic form of human hydatid disease described in Panama, Ecuador, Colombia and Venezuela were considered to be caused by $E$. vogeli (D'Alessandro et al., 1979). The primary localization of cysts is the liver and produces relatively large vesicles brood capsules and numerous protoscolices (Schantz, 1982). The occurrence of $E$. vogeli polycystic echinococcosis in man in the Amazon region in Brazil - State of one was confirmed recently with the description of seven cases (Heneghelli, 1989). Another recent case of polycistic infection caused by $E$. vogeli was confirmed by the morphology of the hooks of protoscolex in a person from the Central region of Brazil- State of Goiás (Paço et al.; 1989). The results of treatment with albendazole were considered very good in 3 out of 5 patient infected with E. vogeli hydatic cysts (Meneghelli, 1989).

Diagnostic of human echinococcosis in South America includes radiologic and immunodiagnostic methods (Purriel et al., 1974; Ramirez et al., 1971). Recent advances in the serodiagnosis of helminthic zoonosis have been review by Schantz (1987). A highly antigenic polypeptide fragment of the recombinant $E$. multilocularis antigen II/3 was produced in Escherichia coli. The sensitivity of this enzymelinked immunosorbent assay was $90 \%$ in 88 patients with polycistic chinococcosis and had a specificity of $99 \%$ among 220 patients with various helmintic infections (Muller et al., 1989). Chemotherapy of cystic echinococcosis in man is in progress with the use of mebendazole, albendazole and praziquantel. The cure rate varies from person to person, but recent reports from China, Bulgaria and Argentina showed that the treatment with albendazole were useful in most of the patients (Ping-Li et al., 1989; Todorov et al., 1989; Martino et al., 1989). The anthelmintic of choice for treatment of infected dogs with $E$. granulosus still praziquantel which is highly effective in a single oral or intramuscular dose of $5 \mathrm{mg} / \mathrm{kg}$ body weight, and completely eliminates all juvenile and adult strobilae.

\section{TAENIOSIS/CYSTICERCOSIS}

Taenia solium Linnaeus, 1758 and $T$. saginata Goeze, 1782 are obligatory associated with man as their definitive 
host and pigs and cattle as intermediate hosts. They are unique zoonoses and have been classified as "Euzoonoses » (Garnham, 1958). In the case of $T$. solium man also can be infected by the larval stage, cysticercus. Larval stages of other species which have domestic dog as definitive host and sheep as primary intermediate host like $T$. multiceps Leske, 1780 and T. hydatigena Pallas, 1766 can also infect man.

T. solium is endemic in most of the developing countries. A survey conducted in Latin America in 1977 showed swine cysticercosis in over $1 \%$ of pigs slaughtered in Brazil, Honduras, Guatemala, Costa Rica, Nicaragua Peru and El Savador (Schenone and Letonja, 1977). Today the percentage of cysticercosis in Brazil it is around $0.15 \%$ of the pigs slaughtered in veterinary inspected abattoirs (Nunes, 1986). However it does not means that the risc of contamination decreased significantly in rural areas were pigs are still kept around houses and grow freely. Diagnostic of cerebral cysticercosis by computerized tomography is now widely used and it is a useful method to evaluate the results of chemotherapy. Mebendazole, praziquantel and albendazole have been used in treatment of human cysticercosis.

T. saginata is widespread in most cattle breeding countries in the world. Transmission of this parasite depend more on the human habit of eating raw or semiraw beef dishes. The rate of bovine cysticercosis during the last years in veterinary inspected abattoirs in Brazil is around $5 \%$.

Control of human taeniosis/cysticercosis by development of vaccines it is a promising alternative in the coming years by vaccination of intermediate hosts (Lloyd, 1987).

Several parasitic zoonoses important in South America which occurs in other parts of the world but were not covered in this article are for example: trichinellosis, toxocarosis (Larva migrans), dirofilariosis, strongyloidosis, fasciolosis, schistosomosis, toxoplasmosis, sarcocystosis, giardiosis, leishmaniosis and trypanosomosis, as well as, those opportunistic infections in AIDS patients which can cause seven diseases like pneumocystosis, cryptosporidiosis, microsporidiosis and encephalitozoonosis.

The number of cases of human lagochilascariosis is increasing in Latin America. There are 62 cases reported, 46 from Brazil and a lethality rate of $6.5 \%$ (Fraiha et al., 1989). Parasitic tumoral lesions are frequent in the neck or the ear regions with presence of adult nematodes, as well as eggs and larval stages. Lagochilascaris minor was described by Leiper in 1909, from two human cases in Trinidad. All the other cases have been confirmed as caused also by L. minor. Lagochilascariosis in domestic cat and dog are similar regarding development of tumoral lesions, abscess and presence or adult parasites. However, two species have been found in both cats and dogs, $L$. minor and L. major Leiper, 1910. The original description of L. major is from intestine of an african lion, Felis leo sabakiensis. The hypothetical life cycle of $T$. minor includes wild felids as definitive host and man, domestic cats and dogs as accidental hosts (Sprent, 1971; Fraiha et al., 1989). Egs of $L$. minor hatches spontaneously in water at room temperature without presence of digestive enzymes. Based on these facts there are several questions that can be asked, like: Why does L. minor goes thru full development in accidental hosts? Why the infection in cats which are probable related to definitive hosts produce tumoral lesions like in man? Does L. minor needs an intermediate host to develop in the intestine of definitive host? If infections are caused by ingestion of free larval in water, do they go thru hepatic-pulmonary tract before migration to the neck region or do they penetrate the oral mucosa? Eighty years have gone since description of $L$. minor from man in Trinidad and we still have many basic questions. Research in parasitic zoonoses like echinococcosis and taeniosis have now more than two centuries and we still have a lot to find out to benefit of mankind.

\section{RÉFÉRENCES}

Blood B. D., Lelijveld J. L. : Studies on sylvatic echinococcosis in southern South America. Z. Tropenmed. Parasitol., 1969, 20, 475-482.

Cameron T. W. M. : The incidence and diagnosis of hydatid cysts in Canada: Echinoccocus granulosus var. canadensis. Parassitologia [Rome], 1960, 2, 381.

Costa G. M., Flores M. L., Silva S. F., Moreira W. S. : Projection to hidatidosis cattle and sheep in the Rio Grande do Sul (Brazil). Abstr. XIV International Hydatidology Congress, Porto Alegre, 1989, p. 19.

D’Alessandro A., Rausch R. L., Cuello C., Aristizabal N. : Echinococcus vogeli in man, with a review of human cases of polycystic hydatid disease in Colombia and neighborning countries. Am. J. Trop. Med. Hyg., 1979, 28, 303-317.

Eckert J. : New aspects of parasitic zoonoses. Vet. Parasitol., 1989, 32, 37-55.

Fraiha H., Leão R. N. Q., Costa F. S. A. : Lagoquilascariase humana e dos animais domésticos. Zoon. Rev. Int., 1989, 1, 25-33.

Garnham P. C. C. : Zoonoses of infections common to man and animals. J. Trop. Med. Hyg., 1958, 61, 92-94.

Hatch C., Smyth J. D. : Attempeted infection of sheep with Echinococcus granulosus equinus. Res. Vet. Sci., 1975, 19, 340.

Kuznetsov M. I., Shubaderov V. Y. A., Tiltin B. P. : Biological morphological and immunological features of Echinococcus granulosus in sheep and pigs in various regions of the U. S. S. R. reprinted in Helminthol. Abstr., 1977, 46, 2066.

Larrieu E., De La Fuente R., Aquino A., Costa M. T., Dapcich C., Bigatti R. : Contrôle de la hydatidosis en la Provincia de Rio Negro, Argentina. Abstr. XIV International Hydatidology Congress, Porte Alegre, 1989, 25.

Leiper R. T. : A new nematode worm from Trinidad, Lagochilascaris minor. Proc. Zool. Soc. Lond., 1909, 2, 742-743.

Lloyd S. : Cysticercosis. In: Soulsby E. J. L. (Editor), Immune Responses in Parasitic Infections: Immunology, Immunopathology and Immunoprophylaxis. Trematodes and Cestodes. Vol. 2, CRC Press, Boca Raton, Florida, 1987, 183-212.

Martino O. A. L., Pena M. C., Fainboim H. : Tratamiento con albendazole en hidatidosis humana. Abstr. XIV International Hydatidology Congress, Porto Alegre, 1989, p. 59. 
Meneghelli V. G. : Hidatidose na amazonia brasileira. Abstr. XIV International Hydatidology Congress, Porto Alegre, 1989, 79-80.

Muller N., Gottstein B., Vogel M., Flury K., Seebeck T. : Application of recombinant Echinococcus multilocularis antigen in an enzyme-linked immunosorbent assay for immunodiagnosis of human alveolar echinococcosis. Mol. Biochem. Parasitol., 1989, 36, 151-159.

Nunes E. A. F. : O estado sanitário do rebanho suíno e os prejuízos decorrentes de condenaçóes ocasionadas por algunas doenças infecciosas e parasitárias no RS, Brasil. Hora Vet., 1986, 6, 35-43.

Oqueta M. V. : Control de la hidatidosis en Chile. XIV International Hydatidology Congress, Porto Alegre, 1989, 180-192.

- Oqueta M. V., Guinez S. C., Bonilla C. : Diagnostico de situacion de hidatidosis ovina y equinococcosis canica XI region Chile. Abstr. XIV International Hydatidology Congress, Porto Alegre, 1989, p. 38.

Paço J. M., Santos M. A. Q., Komma M. D., Alencar R. C. : Hidatidose policistica humana por Echinococcus vogeli Rausch and Bernstein, 1972 no Estado de Goiás. Abstr. XI Congresso Brasileiro Parasitologia, Rio de Janeiro, 1989, p. 99.

Ping-Li Y., Pei-Fan Z., Hao W. : Therapeutic efficacy of albendazole (ABZ) in the treatment of hepatic hydatid disease. Abstr. XIV International Hydatidology Congress, Porto Alegre, 1989, p. 53.

Schantz P. M., Colli C. W. : Ecchinococcus oligarthrus (Diesing, 1963) from Geoffrey's cats (Felis geoffroyi, D'Orbigny and Gervais) in temperate South America. J. Parasitol., 1973, 59, 1138-1140.

Schantz P. M., Lond R. D., de Zavaleta O. : Echinococcus in the South America red fox (Dusicyon culpaeus) and the European hare (Lepus europaeus) in the province of Neuquen, Argentina. Ann. Trop. Med. Parasitol., 1972, 66, 479-485.

Schantz P. M., Cruz-Reyes A., Colli C., Lord R. D. : Sylvatic echinococcosis in Argentina. I. On the morphology and biology of strobilar Echinococcus granulosus (Batsch. 1786) from Argentine domestic and sylvatic animal host. Tropenmed. Parasitol., 1975, 26, 334-344.

Schantz P. M., Colli C., Cruz-Reyes A., Prezioso U. : Sylvatic echinococcosis in Argentina. II. Susceptibility of will carnivores to Echinococcus granulosus (Batsch, 1786) and host-induced morphological variation. Tropenmed. Parasitol., 1976, 27, 70-78.

Schenone H., Reyes H. : Frecuencia de hidatidosis, cysticercosis y triquinosis en individuos folecidos pro muerte violenta en Santiago de Chile (1947-1966). Bol. Chil. Parasitol., 1971, 33, 62.

Sousa O. E. : Development of adult Echinococcus oligarthrus from hydatids of naturally infected agoutis. J. Parasitol., 1970, 56, 197.

Sousa O. E., Thatcher V. E. : Observations on the life-cycle of Echinococcus oligarthrus (Diesing, 1863) in the Republic of Panama. Ann. Trop. Med. Parasitol., 1969, 63, 165-175.

Sprent J. F. A. : Speciation and development in the genus Lagochilascaris. Parasitology, 1971, 63, 45-48.

Steele J. H. : Handbook Series in Zoonoses. Sect. C : Parasitic Zoonoses. Vol. I-III, CRC Press, Boca Raton, Florida, 1982.

Tratcher V. E. : Neotropical echinococcosis in Colombia, Ann. Trop. Med. Parasitol., 1972, 66, 99-105.

Thompson R. C. A., Smyth J. D. : Equine hydatidosis a review of the current status in Great Britain and the results of an epidemiological survey. Vet. Parasitol., 1975, 1, 107-127.

Thompson R. C. A., Lymbery A. J., Hobbs R. P., Elliot A. D. : Hydatid disease in urban areas of Western Australia: an unusual cycle involving wertern grey kangaroos (Macropus fuliginosus), feral pigs and domestic dogs. Aust. Vet. J., 1988, 65, 188-190.

Todorov T., Vutova K., Mechkov G., Tonchev Z., Lazarova I. : Experience in the chemotherapy of severe, inoperable echinococcosis in man. Abstr. XIV International Hydatidology Congress, Porto Alegre, 1989, p. 57.

Who : Parasitic Zoonoses. Tech. Rep. Serv. Nr. 637, Wld. Hlth. Org., Geneva, 1979.

Williams R. J., Sweatman G. R. : On the transmission biology and morphology of Echinococcus granulosus equinus, a new subspecies of hydatid tapeworm in horses in Great Britain. Parasitology, 1963, 53, 391-407.

Zenkov A. V. : Some biological differences of E. granulosus from pigs and sheep (in Russian). Tr. Uses. Inst. Gelmintol. 18:89 (in: Helminthol. Abstr., 1971, 44, 474, 1975). 